\title{
Problems Encountered by the Twelfth Grade Students of MAN 2 Padang in Answering High Order Thinking Skill Questions in Reading Explanation Text
}

\author{
Dini Wahyuni ${ }^{1}$ and Jufrizal ${ }^{2}$ \\ ${ }^{1}$ UniversitasNegeri Padang, West Sumatera Indonesia, $\triangle$ (e-mail)diniwahyuni2501@gmail.com \\ ${ }^{2}$ UniversitasNegeri Padang, West Sumatera Indonesia, $\triangle$ (e-mail) juf_ely@yahoo.com
}

\begin{abstract}
The aim of this research was to describe the problems encountered by the twelfth grade students of MAN 2 Padang in answering high order thinking skill questions in reading explanation text. The design of this research was descriptive qualitative research. The number of population were 461 students. The data were collected through interview. Based on the result of data analysis, it was found that the problems encountered by the students were the students had less practice in answering HOTS questions, the students do not have enough time to thoughtfully complete the test and the students found many unfamiliar vocabularies. Besides, to find out the causes of students' problems in answering HOTS questions, the researcher also used semi structure interview. It was found that the students had less interesting in following the lesson, limitation of time and vocabulary knowledge or mastery.
\end{abstract}

\section{Keywords: Students' Problems, Answering HOTS Questions, Reading}

\section{INTRODUCTION}

Questioning is a skill communication of both teacher and students. In classroom settings, providing students with some questions will enhance their participation while studying. It can be the major reason why teachers need to provide their students with some questions. Teacher questions are defined as instructional guideline or the way of teacher in stimulating the students to guess the content elements to be learned and directions for what the students are to do and how the students are to do it (Cotton, 1988). By giving the students such questions, it will help them to think deeply and also for checking their understanding toward the material. The questioning which is involved in the intructional process can be divided into the questioning given by the teacher orally and written form.

In answering the questions the students are provided more time to think and articulate their answer and can greatly extend classroom conversation and learning. Hall (2016) states that questioning is the best way for the teacher to find out her/his students knowledge. By posing a question to the class, it will allow the students to think, and then call on a student is one simple strategy for engaging students in better academic discourse. As stated by Newman (1993), high order thinking skills challenge students to interpret, analyze, or manipulate information. High order thinking skill questions help the students to learn trough activating their brains and answering different types of question also helps to develop students' knowledge and understanding of different topics.
Higher order thinking takes place when new information is analysed, interpreted, evaluated, explained in relation to the existing information in the mind to come up with better understanding, elaboration, new conclusion and new ideas in form of written texts, artistic expression and solutions to solve non-routine problems (Lewis and Smith in Yusoff and Seman : 2018). In addition, high order thinking skill questions are those that the students cannot answer just by simple recollection or by reading the information from the text. It puts advanced cognitive demand on students. Those questions encourage students to think beyond literal questions.

There are many kinds of learning material that are given by the teacher to the students one of them is providing the students with a text followed by some questions. High order thinking skill questions are involved to check students' understanding. The students have to use their own reaction, feelings, perception, values and life experiences as starting points for answering the question. As stipulated by the curriculum 2013 which demands the students to be able to answer high order thinking skill questions, the teacher provides the students with some questions which encourage the students to think deeply. As a matter of fact, the students often get problem to apply those points. The problems appear when the students try to convey their idea and their understanding toward the text. It occurs since they still do not know how to answer the questions, the lack of vocabulary, their capability in arranging the sentences, and the students do not focus on the question wordings. 
Based on the phenomenon happened at MAN 2 Padang, the researcher assumes that this research should be conducted. Since students often find difficulties and problems in answering high order thinking skill questions and this kind of research has not ever been conducted by the previous researcher. It was supported by the previous researchers deal with HOTS questions. Wirhasni (2017) did her research about the students' TOEFL reading comprehension viewed from Bloom Taxonomy at IAIN Batusangkar. Based on the result of this study, it was found that students' ability in reading comprehension on TOEFL viewed from Bloom Taxonomy was low. It was found that students found difficulties in answering comprehension, analysis, synthesis and evaluation questions level. It indicated that the students had limitation vocabularies, the difficulty of the students in finding main idea of the text and students couldn't predict the others meaning of one word. In addition, the students found difficulties in analyzing the information of text with their own understanding. Most of the students did not know how to make summary of the text with own word and they were not able to translete the new words. While, Muslem, Usman \& Febrina (2019) conducted a research about three up levels of cognitive domain of revised Bloom's Taxonomy used in the textbook entitled Bahasa Inggris SMA/MA/SMK/MAK grade $11^{\text {th }}$ semester 1 . Regarding to the result of study, it was found that the most dominant level in textbook was higher order thinking skills (HOTS). It was $66.8 \%$ of $100 \%$ while it was $33.4 \%$ for lower order thinking skills (LOTS). It indicated that the textbook concentrated more on higher - level thinking questions than lower level thinking.

Based on the explanation above, it can be seen that this research need to be conducted since knowing the students' problems will help the students to enhance their grade particularly in reading comprehension.

\section{REVIEW OF RELATED LITERATURE}

Questions have always been the major stock in trade for teachers and have been recognized as a valuable tool to assist students to learn (Glasson, 2005). Many experts argue that question becomes the most effective tool for the teacher to stimulate the students to learn and to think. Regarding to this opinion, the researcher argues that question that is provided by the teacher to the students should consist of critical thinking question, it encourages the students to share their ideas and knowledge without focus on the content of the textbook, yet it focuses on their mindset so that the communicative learning can be applied in the classroom. The role of students not only as a receiver information, but they also can provide their idea as the additional information given by the teacher.

As has been stated by Poole (2003), good questions invite people to open up about themselves and divulge their thoughts and feelings on a wide variety of topics. Good questions, in other side can be defined as questions which require time to think about the answer. To answer good question, the students need to express their idea and it can be the best way for English language learners to enhance their language skills. Regarding to the theories dealing with questioning, it clearly states that giving students with some questions is the most effective way to encourage them to be active students, to think and share ideas. There are various types of question given by the teacher to the students during the instructional process. Not all questions are on the same level. Some questions are easy to answer where other questions may require a great deal of thinking. Anderson, Lorin, Krathwohl \& David (2001) or Bloom's Taxonomy promote effective questioning through a series of six key types of questions that encourage a deeper engagement with students learning. This taxonomy can assist the teachers in designing performance task, crafting questions for conferring with students, and providing feedback on students' work. The level of questions are remembering (C1), understanding (C2), applying (C3), analysis (C4), evaluating (C5), creating (C6). Those types of question are devided into two levels which are low level of questions and high level of questions. remembering, understanding and applying questions belong to low level while analysis, evaluating and creating belong to high level of questions.

The process of comprehending the text is called reading comprehension. Reading comprehension become the main method used by the teacher in the classroom since in English subject, students are provided with some texts which consist of comprehension activity in that process. Healy (2002) states reading comprehension means the process of understanding written words, understanding the content in the reading sources and construction the meaning of text involved in the text. Similarly, Wolley (2011) states that reading comprehension can be stated as the process of catching the idea and meaning in the text. Based on these two theories, it clearly implies that the process of reading does not only involve the process of undertstanding the idea, yet it demands the reader to construct the meaning and information. This process includes judging, concluding or reasoning from given information. It can be inferred that this process is crucial in reading process.

According to Ivar Braten \& Helge Stromso (2007:196) in Hansen (2016), reading is an interactive process, the process where comprehend the text is the result of joint efforts from the author and the reader. Based on this opinion, the researcher reviews that interacting with a text requires readers to ask themselves questions about the text, visualize what they read, determine importance and use background knowledge to build comprehension. Yet, the interaction involves both readers and writer. It happens since the idea shared by the writer in the text are combined with the reader interpretation and knowledge toward the text.

Regarding to those theories, it can be stated that reading helps the students to enrich their vocabulary knowledge, thinking skills and provides them information needed. It is stated as the active process. It is not only construct the meaning in the text, yet the reader reconstructs her/his own meaning each time while reading. Moore (2013) claims that comprehension depends not only on characteristics of the reader such as prior knowledge 
and working memory, but also on language processes, such as basic reading skills, decoding, vocabulary, sensitivity to text structure, inferencing and motivation. Deals with this opinion, the researcher gets that reading comprehension is the interactive process which is done by the reader while reading. This process involves the reader's ability to construct the meaning and their interpretation toward the text read. Concerning the theories about reading comprehension, the researcher considers that Healy's theory about reading comprehension is more acceptable than the others. It appears from the explanation given which defines that reading comprehension is a process of cathing the idea, an effort to understand the meaning of the text. This process is not only about transforming the content of the text to readers' memories, yet it is more about understanding the meaning of the text as an input for the readers.

\section{METHOD}

The design of this research was descriptive research. It described the problems encountered by the students in answering high order thinking skill questions in reading explanation text. As explained by Gay (1987), descriptive research involves collecting data in order to test hypothesis or answer the question concerning the current status the subject of the study, and descriptive research is useful to investigate a variety of educational problems.

The data were gained by interviewing the students of MAN 2 Padang. It was conducted in order to know the problems encountered by the students in answering high order thinking skill questions in reading explanation text and causes of students' problems in answering high order thinking skill questions in reading explanation text.

\section{DATA ANALYSIS AND DISCUSSION \\ 1. Problems Encountered by the Students in Answering HOTS Questions in Reading Explanation Text}

In answering high order thinking skill questions, most students will find some problems that affect their achievements in the test. Many problems that might be encountered by the students in answering high order thinking skill questions. In order to find the students' problems in answering high order thinking skill questions in reading explanation text, the researcher interviewed 10 students who belonged to low ability students. Based on the data analysis, it was found that there are four problems encountered by the students; less practice, students do not have enough time to thoughtfully complete the test, unfamiliar vocabularies and sentence patterns.

First, less practice was the students' problems in answering high order thinking skill questions. There is obviously some truth to the idea that practice is connected to students' proficiency. Students who had less practice will face some problems in their academic achievement. Dealing with the finding of this research, it was found that the students didn't practice by themselves in answering high order thinking skill questions, but actually high order thinking skill as a cognitive skill is highly needed by students in every education levels and courses. As stated by Lim, Tang \& kor (2012), to develop or maintain one's specific skills, the subskills built through drill and practice should become the building blocks for more meaningful learning. Without practice students often are in the dark about how well they are learning. In other words, it is important for the students to practice before coming up to the real test.

This finding is quite in line with the results of the researches conducted by Mahmud (2014), Halim \& Ardiningtyas (2018) who found that less practice was indicated as the students' problems in answering questions. In their research, it was found that the students didn't commit their time to the course before doing the test. The students said that they had limited time to join the course. It can be said that well preparation will affect the students' achievement. Practice before doing a test is highly needed in order the students are familiar with the questions.

Second problem found was students do not have enough time to thoughtfully complete the test. When the students are provided with some questions, they have to consider the duration to complete the whole questions. In this research, the students said that they couldn't answer the all questions with the time given. It was indicated by the level of questions provided to the students. This condition actually deals with the time management of students. The students spent more time while answering the questions since they couldn't manage their time to complete the all questions. Alsalem, et. al (2017) say that time management plays a vital role in improving students' academic performance. To achieve the goal of learning, students should be more careful with the time consuming especially while doing a test.

Parallel with the research conducted by Rohmah (2017), she also found that the problems encountered by the students in answering questions is students do not have enough time to thoughtfully complete the test. In this case, most students argue that they do not have enough time to answer the questions given by the teacher. They spend their time to be focus in finding out the answer of the difficult questions.

The third problem was the students found many unfamiliar vocabularies. For EFL learners, the biggest obstacle in mastering English is vocabulary. Without enough vocabularies the students cannot communicate with other by using English. Vocabulary is a fundamental element of language proficiency and its acquisition is a main factor of effective communicative skills. Acquiring a deep and rich vocabulary knowledge can help the students to convey their mesasage more efficiently (Ahmed, 2017). In fact, the students found many unfamiliar vocabularies so that they couldn't understand the idea of the text and get the meaning of the questions.

Simillar with the research conducted by Puspita (2007), she identified that unfamiliar vocabularies is the students' problems in answering questions. It was hard for the students to understand the text effectively without knowing the meaning of each word. In other words, 
reading comprehension and answering questions are strongly correlated. Vocabulary cannot be separated with reading comprehension and answering questions. In order to be able to answer the questions effectively the students have to enrich themselves with large number of vocabularies.

\section{Causes of Students" Problems in Answering HOTS Questions in Reading Explanation Text}

Since the students had problems in answering high order thinking skill questions in reading explanation text, there must be some causes which resulted those problems. Based on the data analysis and finding, there are four causes found in the students' problems in answering high order thinking skil questions. They are less interesting in following the lesson, limitation of time, vocabulary knowledge or mastery and grammar knowledge.

First, less interesting in following the lesson made the students had less practice. According to Abrantes, Seabra \& Lages (2007), students' interest reflects input into the course, such as attention level in the classroom, interest in learning the material, perception of a course's intellectual challenge, and acquired competence in the field. When the students do not have any interest in learning they will not have initiative to practice or to learn by themselves. It was proven by the finding of this research. The students do not have any interest in following English. They argue that English is difficult subject for them. Learning a language can be tricky, challenging and sometimes frustrating for some students who do not have any interest in it.

Slameto in Saswandi (2014) says that interest is persisting tendency to pay attention and enjoy some activities and content. When the students do not enjoy themselves while learning English, it means that they do not have any interest in learning English. Being interested in something can mean that the students care about it. Concerning with this circumstance, the teacher has to get the students involved in every activities that make them enjoy to learn English.

Parallel with the research conducted by Padmaningsih (2013), it was found that students do not show any interest in English since they got difficulty in understanding the teacher's instructions. When the students faced some obstacles which cannot be reduced while learning, they tend to give up and do not have any effort to foster their motivation in learning. It cannot be denied that English become one of difficult subject for EFL learners. Learning English as a foreign language is not as easy as students learn their mother tounge. As an educator who takes a vital role in the classroom, the teacher must highlight the students' interest to achieve the success of teaching and learning.

Next cause is limitation of time. Time management is important and it may actually affect students'achievement in answering high order thinking skill questions. While answering high order thinking skill questions, the students are provided with time limitation that make them have to be able to manage it as well. Answering high order thinking skill questions will consume much time. It is caused since the students need to produce their critical and logical thinking. The answer of the questions cannot be found in the text, yet the answer come from students' point of view which based on their background knowledge. To find out the answer of the questions the students spent more time. The time given is not enough for the students to complete the all questions although the time given is suitable to answer the all questions. Students who do not complete the all questions based on the time given will find problem in doing a test. In this research, it was found that the students were consuming more time. The amount of time students spend on a question has a serious effect on the students' achievement.

In line with the research conducted by Padmaningsih (2013), it was found that reading comprehension tests require the students to learn information in a short space of time and recall the information immediately afterward. It was indicated that the students often spend their time in answering the questions. Similar with the finding of this research, limitation of time is considered as the cause of students problem in answering high order thinking skill questions.

Then, vocabulary knowledge or mastery is also identified as the cause of students' problems in answering high order thinking skill questions. Vocabulary knowledge or mastery plays an important role in reading comprehension. There are many reasons why the students often get problem with vocabulary knoweldge. Hyso \& Tabaku (2011) say students often fail to spontaneously learn the meaning of previously unknown words since they failure to notice the unknown words as they believe they know it, wrong guessing and lack of systematic work with new vocabulary.

Nurjanah (2018) also found that the cause of students' problems in answering question is vocabulary knowledge or mastery. Students are indicated have lack vocabulary and it is caused by their vocabulary knowledge. Vocabulary knowledge or mastery is one of factor to master English as foreign language. In other words, the larger vocabulary the students have, the better they perform their language. Answering questions is part of English learning activity that will be done by the students. It is important for the students to enrich themselves with a large vocabularies. It is impossible for the students to catch the idea of the text and understand the meaning of questions involved in reading comprehension test. In this research, it was identified that the couldn't get the meaning of the questions given. They needed to ask their friends about the unfamiliar words or even they needed to look at the dictionary. It seems that the students' vocabulary mastery are not good enough.

\section{CONCLUSION}

Students' ability in answering high order thinking questions were not good enough. It happened since the students encountered some problems in answering the questions. The problems should be consciously realized by both students and teacher. The 
problems appeared were the students had less practice in answering high order thinking questions, the students do not have enough time to thoughtfully complete the test and the students found many unfamiliar vocabularies. The problems need to be detected by the English teacher of MAN 2 Padang earlier. The problems encountered by the students were caused by some factors. The causes were students had less interesting in following the lesson, limitation of time and vocabulary knowledge or mastery. Thus, in enhancing the students' ability and reducing the problems encountered by the students in answering high order thinking questions, it should be considered to emphasize on introduce the students with high order thinking questions. It can be done by strengthening the activities more on practice to answer high order thinking questions particularly in the form of essay questions in order the students are familiar with the questions.

\section{REFERENCES}

[1] Abrantes, J. L, Seabra, C \& Lages, L. F. 2007. Pedagogical Affect, Students' Interest and Learning Performance. Journal of Business Research. Elsevier.

[2] Ahmed, A. A. J. E. 2017. The Role of Vocabulary Learning Strategies in Enhancing EFL Learners' Writing Skills. Intrenational Journal of Humanities Social Sciences and Education. Vol. 4. Pp. 41-50.

[3] Alqahtani, M. 2015. The Importance of Vocabulary in Language Learning and How To Be Taught. International Journal of Teaching and Education. Vol. III, pp. 21-34. Saudi Arabia.

[4] Alsalem, W. S. Y, Alamodi, L. A, Hazazi, A. T. M, Shibah, A. M, Jabri, S. A \&Albosrour, Z. A. 2017. The Effect of Time Management on Academic Performance among Students of Jazan University. The Egyptian Journal of Hospital Medicine. Vol. 69 (8), Page 3042-3049.

[5] Anderson, Lorin W, Krathwohl, David, R. (Eds). 2001. A Taxonomy for Learning, Teaching, and Assessing: A Revision of Bloom's Taxonomy of Educational Objectives. Addison Wesley: Longman.

[6] Cotton, K. 1988. Classroom Questionning. School Improvement Research Series.

[7] Gay, L.R. 1987. Educational Research. Ohio: Merril Publishing Company.

[8] Glasson, S. 2005. Hooked On Questioning, How the Teacher-Librarian Can Change Questioning Practices In Their Schools. Cranbrook School: Australia.

[9] Hall, G. 2016. The Importance of Questioning. https://garyhall.org.uk/importance-ofquestioning.html. accessed on January, 222019.

[10] Healy, C. 2002. Reading: What the Experts Say. The Lowdon on the National Reading Panel. PEATC.

[11] Hyso, K \& Tabaku, E. 2011. Importance of Vocabulary Teaching to Advance Foreign Language Students in Improving Reading Comprehension. Problems of Education in the 21th Century. Vol. 29.
[12] Lim, C. S, Tang, K. N \& Kor L. K. 2012. Drill and Practice in Learning (and Beyond). Encyclopedia of the Sciences of Learning. Springer.

[13] Mahmud, M. 2014. The EFL Students' Problems in Answering the Test of English as a Foreign Language (TOEFL): A Study in Indonesian Context. Theory and Practice in Language Studies, Vol. 4, No. 12, pp. 2581-2587. FBS UNM, Makassar.

[14] Moore, A. L. 2013. A research Review of Cognitive Skills, Strategies, and Intervention for Reading Comprehension. Retrieved from Learningrx.com.

[15] Muslem, A, Usman, B, Febrina. 2019. Analysis on Reading Comprehension Questions By Using Revised Bloom's Taxonomy on Higher Order Thinking Skill (HOTS). English Education Journal. Universitas Syiah Kuala, Banda Aceh.

[16] Newman, F. M.(1990) Higher Order Thinking in Teaching Social Studies: A rationale for the assessment of Classroom Thoughtfulness. Journal of Curriculum Studies, 22(1), pp. 41-56.

[17] Nurjanah, R. L. 2018. The Analysis on Students' Difficulties in Doing Reading Comprehension Final Test. Journal of English Language Literature and Teaching. Universitas Ngudi Waluyo.

[18] Padmaningsih, S. 2013. Student's Difficulties in Answering Multiple-Choice Questions in Narative Text at Eight Grade of SMP Muhammadiyah Karangrayung. Muhammadiyah University of Surakarta.

[19] Poole, G. 2003. The Complete Book of Questions. Willow Creek Association. Zondervan.

[20] Puspita, A. 2017. Students' Difficulties in Comprehending English Reading Text at Second Grade Students of MAN 2 Metro. University of Lampung.

[21] Rohmah, A, A. 2017. Problems Faced by the Eleventh Grade Students of MAN 2 Gondangrejo in Answering Englih Final Test for the First Semester in Academic Year 2016/2017. State Islamic Institute of Surakarta.

[22] Saswandi, T. 2014. Teaching Style and Students' Interest in Learning English. Jurnal Penelitian Universitas Jambi Seri Humaniora. Vol. 17. Pp. $33-$ 39.

[23] Wardani, S. I. 2015. Improving Students Vocabulary Mastery Using Word Mapping Strategy. Okara. Vol. 1.

[24] Wirhasni, D. 2017. An Analysis of Students' TOEFL Reading Comprehension ViewedFrom Bloom Taxonomy at IAIN Batusangkar Regency. Universitas Negeri Padang. Thesis.

[25] Wolley, G. 2011. Reading Comprehension: Assisting Children with Learning Difficulties. Springer Science + Business Media.

[26] Yusoff, W. M. W., \& Seman, S. C. (2018). Teachers Knowledge of Higher Order Thinking and Questioning Skills: A Case Study at a Primary School in Terengganu, Malaysia. International Journal of Academic Research in Progressive Education and Development, 7(2), 45-63. 